\title{
KEBIJAKAN DIVIDEN DI BURSA EFEK INDONESIA PADA PERUSAHAAN KELOMPOK LQ 45
}

\author{
Sri Hasnawati \\ Fakultas Ekonomi dan Bisnis, Universitas Lampung \\ Sri.hasna2015@gmail.com
}

\begin{abstract}
Dividend policy is very important in Finance Management. But until now the concept of dividend policy remains a debatable issue: should corporate profits be distributed or should they be kept as return earnings? In order to address the issue, research on public companies listed on the Indonesian stock exchange on LQ 45 companies is conducted. A model of multiple regression is used to explain what factors should be considered in carrying out the company's dividend policy. The result of this study shows that main factors that should be considered in distributing the cash dividend are investment and leverage that may have an impact on the reduction of dividend. Size and liquidity variables do not affect dividend policy. When this study is related to agency theory, it seems that the companies in the LQ 45 have reduced agency conflict by increasing investment from internal and external sources. The creditors supplied external sources to increase management control. The dividends were distributed in order to give a return on shareholders.
\end{abstract}

Keywords: Dividend, Investment, profitability, leverage, size, liquidity.

\begin{abstract}
Abstrak: Kebijakan dividen merupakan hal penting dalam manajemen keuangan. Namun sampai saat ini konsep kebijakan dividen masih menjadi pro dan kontra, apakah laba yang dihasilkan akan dibagikan atau ditahan untuk mengembangkan usaha perusahaan. Untuk menjelaskan perdebatan tersebut maka dilakukan penelitian pada perusahaan publik yang terdaftar di BEI kelompok perusahaan yang masuk dalam LQ 45 selama tahun 2005-2014. Penelitian menggunakan model regresi berganda untuk menjelaskan faktor apa saja yang dipertimbangkan dalam menjalankan kebijakan dividen perusahaan. Hasil penelitian menyimpulan bahwa yang dipertimbangkan dalam pembagian dividen kas perusahaan adalah investasi dan leverage berdampak terhadap pengurangan dividen sedangkan profitabilitas berdampak pada peningkatan dividen kas. Variabel size dan likwiditas tidak mempengaruhi kebijakan dividen. Dikaitkan dengan agency theory, tampak perusahaan dalam kelompok LQ 45 mengurangi konflik keagenan dengan meningkatkan investasi yang dibiayai dari sumber internal dan eksternal. Sumber eksternal untuk menambah kontrol manajemen oleh pihak kreditor dan dividen dibagikan untuk memberikan return atas dana yang ditanamkan pemegang saham.
\end{abstract}

Kata kunci: Dividen, Investasi, profitabilitas, leverage, size, likwiditas.

\section{PENDAHULUAN}

Kebijakan dividen masih merupakan masalah yang mengundang perdebatan karena ada beberapa pendapat mengenai dividen. Pertama, pendapat yang mengatakan dividen dibagi sebesar-besarnya (dividend relevant); Kedua, kebijakan dividen tidak relevan; dan 
ketiga perusahaan membagi dividen sekecil mungkin, Hasnawati (2005).

Manajer keuangan dalam menetapkan kebijakan dividen harus mempertimbangkan seberapa jauh kebutuhan sumber pembiayaan internal yang dibutuhkan dalam membiayai operasional. Hal ini harus diperhitungkan dengan tepat dan dapat dipertanggungjawabkan, mengingat laba yang ditanamkan kembali untuk kegiatan operasional adalah hak para pemegang saham yang tidak dibagikan sebagai dividen. Atas dasar itulah manajemen harus mempertimbangkan risiko dan hasil yang akan diperoleh saat memutuskan tidak membagi dividen.

Laba ditahan merupakan salah satu sumber dana internal. Rasio pembayaran dividen (dividend pay out ratio) menentukan jumlah laba yang ditahanKarena laba ditahan akan dijadikan sumber pembiayaan dan investasi yang diharapkan dapat memaksimumkan nilai perusahaan Ozuomba et al (2016); Hasnawati (2005). Wheelen \& Hanger (2014) mengatakan bahwa manajemen dividen bagi shareholders merupakan salah satu bagian penting dalam strategi keuangan perusahaan. Perusahaan pada industri dengan pertumbuhan yang tinggi seperti computer\&software computer sering tidak mengumumkan/membagikan dividen. Mereka menggunakan uang yang merupakan dividen shareholders untuk mendanai pertumbuhan perusahaan yang tinggi tersebut. Kesuksesan perusahaan dalam pertumbuhan penjualan dan keuntungan, akan tercermin pada tingginya harga saham yang pada akhirnya menghasilkan capital gain yang besar ketika shareholders menjual sahamnya. Sebaliknya, perusahaan seperti electric utilities tidak memiliki pertumbuhan yang tinggi, sehingga mereka harus mendukung peningkatan nilai perusahaan dengan menawarkan sejumlah besar dividen dan dibayarkan secara konsisten. Untuk itu, meskipun perusahaan memperoleh keuntungan yang besar belum tentu akan membagikan dividen. Hal ini dilakukan untuk menjaga likuiditas. Pernyataan ini didukung oleh Sartono (2008) yang menyatakan bahwa likuiditas perusahaan merupakan pertimbangan utama dalam kebijakan pembayaran dividen karena pembayaran dividen bagi perusahaan merupakan kas keluar. Semakin besar posisi kas dan likuiditas perusahaan, semakin besar kemampuan perusahaan untuk membayar dividen.

Perusahaan yang sedang mengalami pertumbuhan dan menginginkan profitabilitas tinggi akan memerlukan dana yang cukup besar guna membiayai investasinya, dengan demikian ada kemungkinan kurang likuid dan pembayaran dividen dapat ditunda, karena banyak dana yang diperoleh digunakan untuk investasi.

Studi yang dilakukan Harahap \& Wardhani (2013) menyimpulkan bahwa pemegang saham dengan tarif pajak yang berbeda tidak sepenuhnya menyetujui investasi/dividen perusahaan. Pemegang saham dengan tarif pajak tinggi akan lebih menyukai bila perusahaan melakukan lebih banyak investasi. Sebaliknya pemegang saham dengan tarif pajak rendah lebih menyukai pelaksanaan investasi yang sedikit. Bila dikaitkan dengan penelitian tersebut, maka kebijakan dividen dapat berdampak terhadap meningkatkan atau menurunkan nilai perusahaan apabila kebijakan dividen yang diambil tidak memenuhi keinginan pemegang saham yang memiliki clientile yang berbeda.

Selain alasan investasi pembagian dividen diberikan karena dapat dijadikan alat monitoring sekaligus bonding bagi manajemen dan pengurangi masalah keagenan Jensen \& Meckling (1976); Harahap \& Wardhani (2013). Pembagian dividen akan membuat pemegang saham mendapat tambahan return selain capital gain. Dividen juga dapat membuat pemegang saham mempunyai kepastian pendapatan dan dapat mengurangi agency cost of equity karena tindakan perquisties yang dilakukan manajemen terhadap cash flow perusahaan seiring dengan menurunnya biaya monitoring akibat kepercayaan 
pemegang saham akan kebijakan manajemen yang menguntungkan pemegang saham.

Danis \& Igor (2007) mengemukakan beberapa alasan mengapa dividen tetap dibagikan meskipun pada saat yang sama perusahaan memiliki kesempatan investasi yang menarik, dan perusahaan mendanai perusahaan dari sumber eksternal. Pertama, pembayaran dividen kas merupakan suatu yang lazim. Artinya kegagalan melakukan pembayaran dividen dapat dianggap suatu aib yang memalukan. Selain itu pembayaran dividen dapat memberikan sinyal tentang masa depan perusahaan Kedua, dividen menyajikan sales point bagi investment banking, karena beberapa investor institusional hanya akan membeli saham perusahaan yang membayar dividen. Ketiga, shareholders sering minta dividen, walaupun perusahaan memiliki kesempatan untuk melakukan investasi kembali dari seluruh dana yang mungkin cukup besar. Keempat, ada suatu keyakinan yang tersebar luas, bahwa pembayaran dividen akan mengakibatkan harga saham yang lebih tinggi. Sejalan dengan pendapat Pearce \& Robinson (2008) bahwa stabilitas earnings dan dividen sering memberi kontribusi positif kepada harga pasar saham perusahaan. Selanjutnya Priya \& Mohanasundari (2016); Lintner (1962) memberikan alasan rasional bahwa perusahaan enggan untuk menurunkan dividen. Karena jika perusahaan menurunkan dividen, akan dianggap sebagai sinyal yang buruk dan dianggap perusahaan memiliki risiko yang tinggi dan prospek yang kurang menguntungkan. Berdasarkan pada hasil studi sebelumnya dan konsep yang masih diperdebatkan bagaimana sebaiknya kebijakan dividen yang dapat meningkatkan memaksimumkan kemakmuran pemegang saham, maka penulis tertarik untuk mengetahui faktor apa sajakah yang mempengaruhi kebijakan dividen perusahaan go publik di Indonesia khususnya perusahaan yang dikatakan aktif (likwiditas yang tinggi) dalam transaksi selama tahun 2005 sampai dengan 2014?

Berdasarkan pada latar belakang tersebut di atas maka masalah penelitian ini dapat dirumuskan sebagai berikut: (1) Faktor apakah yang mempengaruhi kebijakan dividen perusahaan publik di Indonesia?; (2) Teori kebijakan dividen apakah yang berlaku di Pasar Modal Indonesia?

Tujuan dari penelitian ini adalah mengetahui faktor apa sajakah yang mempengaruhi kebijakan dividen, dan akan mengkaji teori kebijakan dividen apakah yang berlaku di pasar modal indonesia. Secara umum penelitian ini bertujuan untuk menambah dan mengembangkan konsep manajemen keuangan, terutama teori kebijakan dividen di pasar modal Indonesia dalam kaitannya dengan pelaksanaan kebijakan usaha dalam rangka menciptakan iklim usaha yang sehat bagi perusahaan publik. Diharapkan penelitian ini akan memberikan kontribusi teoritis dan empiris. Kontribusi teoritis akan diberikan dari hasil penelitian ini sebagai bahan tambahan untuk proses belajar dan sebagai acuan dalam merumuskan hipotesis pada penelitian selanjutnya. Kontribusi empiris dapat diperoleh dari studi ini, yang bermanfaat untuk pengambilan keputusan bagi perusahaan, manajemen, kreditur, investor, dan pihak lain yang berkepentingan.

\section{KAJIAN TEORI}

Kebijakan dividen relevan menjelaskan, bahwa pembayaran dividen dapat menurunkan nilai perusahaan. Pemikiran ini didasari adanya pajak dividen yang lebih tinggi dari pada pajak capital gain. Juga tidak benar kalau perusahaan harus membagikan semua laba sebagai dividen, hanya karena perusahaan harus membagikan dividen sebesarbesarnya. Laba dibenarkan untuk ditahan jika dana tersebut bisa diinvestasikan dan 
menghasilkan tingkat keuntungan yang lebih besar dari biaya modalnya (memberi net present value positif), dengan harapan dividen di masa yang akan datang akan naik sebagai hasil dari investasi yang dilakukan. Harapan investor untuk memperoleh dividen secepatnya dapat direalisasikan dengan kesediaannya untuk membayar harga atas saham perusahaan dengan lebih tinggi. Pada pasar modal sempurna dan efisien, investor dapat setiap saat menjual atau menginvestasikan kembali dividen yang diterima, sehingga untuk jangka panjang dividen tetap memberikan suatu pendapatan yang tidak berbeda dengan dividen yang tidak dibagikan tapi diinvestasikan oleh perusahaan.

Kelompok lain menganggap dividen tidak relevan (the irrelevant of dividend). Modigliani \& Miller (1961); Priya \& Mohanasundari, 2016; Ozuomba et al, 2016, mengatakan bahwa kebijakan dividen tidak mempunyai pengaruh terhadap nilai perusahaan. Nilai perusahaan ditentukan oleh keputusan pembiayaan dan investasi serta struktur modal yang optimal dan bukan oleh kebijakan dividen atau besarnya laba ditahan. Selanjutnya dikatakan bahwa perusahaan bisa saja membagikan dividen yang besar ataupun kecil, asalkan dimungkinkan menutup kekurangan dana dari sumber eksternal. Jadi yang penting adalah apakah investasi yang tersedia diharapkan akan memberikan net present value yang positif, tidak perduli apakah dana yang digunakan diperoleh dengan menahan laba ataukah dari luar perusahaan dengan menerbitkan saham baru. Dampak dari pilihan keputusan tersebut sama saja terhadap nilai perusahaan. Jadi keputusan dividen adalah tidak relevan (the irrelevant of dividend).

Ozuomba et al, 2016 melanjutkan penjelasanya tentang konsep risidual dividen, mendasarkan pada keputusan membagikan laba pada kebutuhan investasi di masa yang akan datang dan sisanya sebagai dividen. Dengan demikian perusahaan mempertahankan semua kelebihan penghasilan untuk investasi pada proyek dengan NPV positif dan sisa kelebihan laba untuk membayar dividen. Dengan cara tersebut, dividen dianggap sebagai kebijakan pasif dan tidak relevan dalam mempengaruhi nilai perusahaan. Karena, pemegang saham tidak peduli hasil yang diperoleh atas investasi mereka dalam bentuk dividen atau apresiasi nilai sahamnya.

Kelompok berikutnya berpendapat agar dividen dibagi sekecil-kecilnya. Pendapat sebelumnya mengatakan bahwa dividen tidak relevan mendasarkan diri atas pemikiran bahwa membagikan dividen dan menggantikan dengan menerbitkan saham baru mempunyai dampak yang sama terhadap harga saham. Sayangnya analisis tersebut mengabaikan adanya biaya penerbitan saham baru/biaya emisi (flotation cost), yang berkisar antara $2 \%$ sampai $4 \%$. Dengan adanya biaya-biaya tersebut, berarti sebagian kekayaan pemegang saham diberikan kepada berbagai pihak sebagai flotation cost. Jadi bila perusahaan memiliki dana untuk investasi mengapa dana tersebut dibagikan sebagai dividen? Sehingga menimbulkan biaya flotation Easterbrook (1984).Oleh sebab itu, mereka beranggapan dividen sebaiknya dibagi sekecil-kecilnya, sejauh dana tersebut dapat digunakan untuk investasi yang menguntungkan atau memberi NPV positif.

Pendapat dividen dibagi sekecil-kecilnya tampaknya bertentangan dengan pendapat Mollah (2014) mengenai pembagian dividen di negara-negara berkembang. Mereka mengatakan bahwa perusahaan di negara berkembang secara rata-rata melakukan kebijakan pembayaran dividen dengan payout ratio sebesar dua pertiga dari laba perusahaan-perusahaan di negara maju. Perusahaan di negara berkembang lebih mementingkan kebijakan dividen berdasarkan payout ratio dibandingkan dengan besaranbesaran moneternya.

Menurut Clientele theory, dividend puzzle (perdebatan) disebabkan oleh adanya 
investor yang berbeda baik dilihat dari segi usia investor, kelompok investor, dan golongan. Perbedaan tersebut telah menimbulkan preferensi yang berbeda terhadap tinggi rendahnya dividen yang akan mereka terima. Investor individual dengan usia lanjut dan penghasilannya hanya tergantung dari dividen mungkin lebih menyukai dividend payout yang tinggi. Akan tetapi investor dengan penghasilan tinggi akan lebih menyukai dividend payout rendah.

Bird in the hand Theory dari Lintner (1962); Bhattacharya (1979), menjelaskan bahwa investor menyukai dividen untuk menghindari risiko dari pada capital gain yang belum jelas. Karena dividen yang diterima seperti burung di tangan yang risikonya lebih kecil atau mengurangi ketidakpastian dibandingkan dengan dividen yang tidak dibagikan. Kelompok ini berpendapat bahwa peningkatan dividen akan meningkatkan harga saham yang selanjutnya berdampak terhadap nilai perusahaan.

Valipour et al (2009); Ozuomba et al (2016) dan Vojtech, 2012; asymmetry informasi kaitannya antara manajer dan investor. Manajer memiliki lebih banyak informasi tentang perusahaan dibandingkan dengan investor. Dalam kondisi informasi yang tidak seimbang (asymmetric information) para manajer dapat menggunakan strategi dalam kebijakan dividen untuk menangkal isu-isu yang tidak diharapkan oleh perusahaan di masa yang akan datang. Oleh sebab itu dalam kebijakan dividen ini dapat terjadi suatu keadaan di mana besarnya dana sebagai keuntungan yang ditahan dapat digunakan sebagai dasar untuk memberikan informasi yang akan ditangkap sebagai sinyal oleh investor. Investor, yang merasa mempunyai informasi yang lebih sedikit akan berusha menginterpretasikan perilaku manajer. Dengan kata lain, perilaku manajer termasuk dalam perilaku penentuan strktur modal dan besarnya dividen yang akan dibagikan. Oleh sebab itu manfaat pembayaran dividen kepada investor harus dijaga keseimbangannya dengan manfaat atas pendapatan yang ditahan yang digunakan sebagai sumber pembiayaan internal.

Ozuomba et al, 2016 menjelaskan suatu model sinyal (signal model), bahwa tingginya dividen yang dibagikan menunjukkan tingginya performance perusahaan. Pada kondisi informasi tidak seimbang (disparity) tinggi antara manajer dan investor, perusahaan akan memberikan sinyal dengan membayar dividen yang tinggi. Perubahan pembayaran dividen akan ditafsirkan sebagai sinyal kepada para pemegang saham dan investor tentang prospek perusahaan dimasa yang akan datang. Umumnya kenaikan dividen akan dianggap sebagai sinyal positif, sebaliknya penurunan dividen akan dipandang sebagai sinyal negatif tentang prospek laba perusahaan dimasa yang akan datang dan akan menimbulkan perubahan pada harga saham dan kekayaan investor.

Nguyen (2014), meneliti dampak dividen terhadap kemakmuran pemegang saham, menghasilkan suatu kesimpulan bahwa memulai pembayaran dividen (Initiating dividend) meningkatkan kemakmuran pemegang saham. Sejalan dengan Azhagaiah \& Sabarai (2008), kebijakan dividen berdampak signifikan terhadap kesejahteraan pemegang saham.Temuan Nguyen dan Azhagaiah \& Sabari, bertolak belakang dengan penelitian yang di lakukan di Indonesia Sugeng (2016), menemukan bahwa tidak terdapat pengaruh yang signifikan dividend initiation announcement terhadap abnormal return saham perusahaan public di Indonesia.

Dua rasio yang sering digunakan untuk memproksi kebijakan dividen suatu perusahaan yaitu dividend payout ratio, dan dividend yield. Dividend payout ratio diukur sebagai dividen yang dibayarkan dibagi dengan laba yang tersedia bagi pemegang saham. Mollah (2014), mengatakan bahwa perusahaan di Negara berkembang lebih 
mementingkan dividend pay out ratio dari pada besaran moneternya. Sedangkan dividend yield adalah persentase dividen terhadap harga saham periode sebelumnya yang dapat dijadikan proksi sebagai besaran moneternya.

Signaling theory, merupakan teori yang menjelaskan persepsi investor luar tentang prospek perusahaan akibat adanya corporate action. Ozuomba et all (2016) signaling hypothesis menjelaskan bahwa manajer menggunakan pengumuman dividen sebagai sinyal perubahan tentang prospek perusahaan di masa yang akan datang. Peningkatan dividen merupakan sinyal positif, sedangkan penurunan dividen merupakan sinyal negatif bagi investor. Penjelasan tersebut telah dibuktikan oleh Murhardi (2008) dengan mencoba menguji signaling hypothesis, atas kebijakan dividen terhadap return saham. Hasil studi di atas mendukung proposisi tentang teori sinyal bahwa pelaku pasar membuat keputusan dengan menggunakan informasi yang terkandung dalam pengumuman dividen. Artinya bahwa tepri signaling masih relevan dalam mempengaruhi pergerakan harga saham. Pasar bereaksi positif atas meningkatnya dividen kas yang diumumkan. Sebaliknya pasar merespon negatif saat dividen dikurangi atau saat dividen saham dibagikan.

Menurut Van Horne dan Machowicz (2012), beberapa faktor yang mempengaruhi kebijakan dividen perusahaan antara lain: (1) Aturan-aturan hukum; berkaitan dengan penurunan nilai modal, insolvensi (kebangkrutan), dan penahanan laba; (2) Kebutuhan pendanaan perusahaan; (3) Likuiditas; (4) Kemampuan untuk meminjam; (5) Batasanbatasan dalam kontrak utang; (6) Pengendalian. Menurut Sunariyah (2010) dividen dipengaruhi oleh profitabilitas, posisi kas, dan kesempatan investasi perusahaan. Konsisten dengan pendapat Ang (2010) dividen dipengaruhi oleh laba bersih dan price earning ratio, namun Price earning ratio dan pajak berbanding terbalik dengan jumlah dividen yang dibagikan. Selain kedua variabel tersebut dividen juga dipengaruhi oleh leverage, rasio aktivitas, serta variabel makro lainnya seperti tingkat suku bunga, kurs, dan neraca perdagangan. Abbas et al (2016) menyatakan bahwa ukurang berdampak positif dan signifikan terhadap kebijakan dividen. Pernyataan tersebut dapat diartikan ukuran perusahaan dapat mempengaruhi rasio pembayaran dividen perusahaan. Hal ini terjadi karena perusahaan yang memiliki ukuran besar dianggap sudah mapan sehingga mudah melakukan akses ke pasar modal dalam upaya mencari sumber pembiayaan. Sementara perusahaan yang masih baru dan ukuran kecil akan memiliki kesulitan untuk akses ke pasar modal. Kemudahan tersebut akan berdampak terhadap pencarian dana eksternal sehingga laba yang dihasilkan dapat digunakan untuk membayar dividen.

Kerangka Pemikiran dan Hipotesis. Investor/pemegang saham dalam melakukan investasi mengharapkan return investasi yang diperoleh dari capital gain dan dividen. Capital gain belum memberi kepastian, namun dividen memberi kepastian bahwa pemegang saham berhak atas dividen yang dihasilkan dari laba perusahaan. Menurut bird in the hand theory bahwa investor lebih menyukai deviden karena sudah pasti dibandingkan capital gain. Untuk membayarkan dividen perusahaan kepada investor, perusahaan harus memiliki cukup banyak dana likwid. Apabila perusahaan tidak memiliki likwiditas yang baik, maka kemungkinan dividen tidak bisa dibayarkan. Sartono (2008) menyatakan bahwa likuiditas perusahaan merupakan pertimbangan utama dalam kebijakan pembayaran dividen karena pembayaran dividen bagi perusahaan merupakan kas keluar. Semakin besar posisi kas dan likuiditas perusahaan, semakin besar kemampuan perusahaan untuk membayar dividen.

Studi yang dilakukan oleh Easterbrook (1984), menyatakan investasi yang dilakukan perusahaan akan mempengaruhi kebijakan dividen, karena investasi 
membutuhkan dana. Sejalan dengan Ardestani et al (2013) dalam menyatakan bahwa investment opportunity set sebagai indikator kebijakan investasi perusahaan, memiliki pengaruh terhadap keputusan dividen.

Menurut pecking order theory, urutan pendanaan yang dipilih adalah menggunakan dana internal yang bersumber dari laba. Dimana laba adalah sebagian hak para pemegang saham dalam bentuk dividen. Banyak perusahaan tidak hanya dibiayai oleh modal sendiri, tetapi juga didanai oleh hutang. Berkaitan dengan kebijakan hutang/leverage Abbas et al (2016) menyatakan bahwa kebijakan dividen dan struktur modal memiliki korelasi yang positif. Konsisten dengan temuan Muthusany \& John (2010) bahwa perusahaan dengan leverage yang tinggi akan membayar dividen yang rendah untuk menghindari biaya meningkatnya modal ekternal, dan sebaliknya.

Profitabilitas merupakan kemampuan perusahaan untuk menghasilkan keuntungan atas investasi yang dilakukan. Profitabilitas akan menentukan besarnya dividen yang dapat digunakan oleh pemegang saham, atau ditanamkan kembali sebagai investasi. Dalam hubungannya dengan kebijakan dividen, besarnya profitabilitas akan mempengaruhi besar kecilnya pembayaran dividen. Manajemen akan membayarkan dividen untuk memberikan sinyal mengenai keberhasilan perusahaan dalam menghasilkan laba. Perusahaan yang menghasilkan keuntungan tinggi akan membayar dividen dengan porsi yang tinggi juga. Nurhayati (2013) menemukan bahwa profitabilitas mempunyai pengaruh positif dengan Dividen Payout Ratio.

Perusahaan dengan ukuran yang besar diperkirakan akan mampu menghasilkan laba yang besar juga dan sebaliknya. Sehingga perusahaan yang memiliki ukuran yang besar akan mampu untuk membagikan dividen. Selain itu ukuran perusahaan akan menentukan kemudahan dalam pencarian dana eksternal Sartono (2008). Makin besar ukuran perusahaan, makin mudah untuk mendapatkan dana eksternal, demikan sebaliknya. Oleh sebab itu makin besar ukuran perusahaan dividen yang dibagikan semakin besar. Berdasarkan pada kajian pustaka dan kerangka pemikiran tersebut maka hipotesis penelitian dapat dirumuskan sebagai berikut: Kebijakan dividen dipengaruhi oleh likwiditas, leverage, profitabilitas, peluang investasi, dan ukuran perusahaan.

\section{METODE}

Penelitian ini merupakan penelitian hipotesis testing atau riset eksplanatori. Dengan tujuan untuk mengetahui sejauh mana variabel-variabel penelitian mempengaruhi kebijakan dividen di pasar modal indonesia yaitu di bursa efek indonesia khususnya perusahaan yang masuk dalam kelompok LQ 45.

Data yang digunakan dalam penelitian ini adalah data sekunder bersifat kuantitatif, berupa rasio-rasio keuangan dari laporan keuangan yang terbit setiap akhir periode laporan keuangan. Ardestani et al (2013), Subramaniam \& Shaiban (2011) menggunakan bentuk rasio keuangan atas dasar nilai pasar (a firm's market value) dan nilai buku (book value). Alasan tersebut sejalan dengan Denis \& Igo (2007) yang mengatakan bahwa harga saham dan rasio keuangan menggambarkan expektasi atau propek keuangan di masa yang akan datang sebagai refleksi accounting returns hasil kinerja di masa lalu.

Populasi penelitian ini adalah seluruh perusahaan yang tercatat di Bursa Efek Jakarta. Populasi target dalam penelitian ini adalah seluruh perusahaan publik kecuali bank dan lembaga keuangan bukan bank (asuransi, kredit agensi, perusahaan sekuritas) pada tahun 2005 sampai 2015. Alasan ini didukung oleh Jensen\&Meckling (1976): bahwa 
"highly regulated industries such as public utilities or bank will have higher debt equity ratios for equivalent level of risk than the average non regulated firm."

Penelitian ini memiliki dua variabel yaitu variabel bebas (independent) dan variabel terikat (dependent). Sebagai variabel Terikat adalah kebijakan dividen yang diproksi melalui Dividen payout ratio, sedangkan variabel bebas di proksi dengan 5 rasio keuangan yaitu likwiditas, leverage, profitabilitas, peluang investasi , dan ukuran perusahaan.

Dividen payout ratio merupakan kebijakan perusahaan yang berhubungan dengan penentuan persentase laba bersih perusahaan yang dibagikan sebagai dividen kepada pemegang saham. Sebagai variabel terikat, kebijakan dividen dikonfirmasikan melalui variabel terukur seperti yang dilakukan oleh Ardestani et al (2013), Subramaniam \& Shaiban (2011) yaitu dividend pay out ratio.

Rasio likwiditas merupakan rasio yang mengukur kemampuan perusahaan dalam rangka memenuhi kewajibannya. Nurhayati (2013), menyatakan ketersediaan dana kas menunjukkan tingkat dividen yang akan dibagikan. Berdasarkan hal tersebut maka likwiditas dalam penelitian ini di proksi dengan menggunakan cash ratio.

Leverage merupakan rasio untuk mengetahui perbandingan jumlah hutang terhadap jumlah aset yaitu suatu ukuran persentase jumlah dana yang disediakan oleh kreditor. Pemilik perusahaan lebih menyukai memiliki rasio ini yang tinggi, karena tingginya rasio ini dapat memperbesar laba bagi pemegang saham. Berdasarkan pada hal tersebut, maka rasio leverage akan di proksi dengan menggunkan rasio debt to total asset.

Profitabilitas merupakan rasio untuk mengukur kemampuan perusahaan dalam menghasilkan laba. Laba yang dibagikan sebagai dividen adalah laba bersih. Laba bersih adalah laba setelah dikurangi seluruh kewajiban kepada pihak kreditor dan pemegang saham preferen. Oleh sebab itu proksi yang digunakan dalam variabel ini adalah ROI yang menjelaskan hubungan antara net profit dengan Investasi yang dilakukan perusahaan.

Peluang investasi merupakan variabel yang menjelaskan tentang investasi yang sudah dilakukan dan yang akan dilakukan. Variabel penelitian yang diproksi dengan IOS (investment opportunity set) yang mencerminkan actual dan opportunity investasi yaitu: Earning to price ratio. Tingginya earnings to price ratio memberi indikasi akan besarnya proporsi nilai ekuitas yang merupakan atribut dari aset yang dimiliki secara relatif terhadap pertumbuhan di masa yang akan datang Ardestani et al (2013), Subramaniam \& Shaiban (2011)

Ukuran Perusahaan merupakan variabel yang dapat menyatakan besarnya suatu ukuran perusahaan. Umumnya ukuran perusahaan di proksi dengan menggunakan indikator total sales, total asset atau rata-rata penjualan. Pada penelitian ini menggunakan total net sales sebagai indikator size Zainuddin, 2012. Model penelitian yang digunakan dalam penelitian ini adalah regresi linier berganda. Model ini digunakan untuk mengetahui pengaruh variabel bebas terhadap variabel terikat. Sebelum dilakukan analisis, akan dilakukan uji asumsi klasik untuk menguji bahwa model telah memenuhi syarat BLUE. Untuk menguji hipotesis yang dikemukan, akan dilakukan uji statistik $\mathrm{t}$ dan uji statistik $\mathrm{F}$ dengan tingkat kepercayaan $95 \%$.

Persamaan regresi linier berganda dalam penelitian adalah sebagai berikut:

$$
\mathrm{DPR}=\mathrm{a}+\mathrm{b} 1 \mathrm{CR}+\mathrm{b} 2 \mathrm{DTA}+\mathrm{b} 3 \mathrm{ROI}+\mathrm{b} 4 \mathrm{EPR}+\mathrm{b} 5 \ln \text { Sales + et }
$$




\section{HASIL DAN PEMBAHASAN}

Penelitian ini menggunakan data perusahaan publik periode 2005 sampai dengan 2014 yang masuk dalam LQ 45 secara terus menerus. Dalam setiap periode LQ 45 dihasilkan jumlah perusahaan beragam jumlahnya. Yang sesuai dengan ketentuan bursa untuk menentuka kriteria saham yang memenuhi syarat masuk kelompok LQ 45. Selama periode pengamatan perusahaan yang membagi dividen tunai sebanyak 122 perusahaan. Dari 122 perusahaan dihasilkan 316 data dalam kurun waktu 2005 sampai 2014. Dan Setelah dilakukan analisis data yang memenuhi syarat untuk dianalisis sesuai ketentuan kriteria penentuan sampel dalam penelitian sebanyak 297 data penelitian.

Berdasarkan hasil perhitungan statistik deskriptif pada lampiran 1 ditemukan bahwa perusahaan yang masuk dalam LQ 45 selama periode 2005-2014, dan melakukan pembayaran dividen kas kepada pemegang saham rata-rata sebesar 37,65\% dari earning yang dihasilkan. Pertumbuhan investasi perusahaan rata-rata $11 \%$. Size yang menggunakan ukuran ln sales dihasilkan nilai rata-rata 15.3504 dengan standar deviasi sebesar 3.03560. Kemampuan perusahaan untuk memenuhi kewajiban jangka pendeknya rata-rata 2.4 kali. Artinya likwiditas masih terjaga dalam kategori aman sehingga kebijakan pembayaran dividen lebih memungkinkan untuk dibayarkan kepada pemegang saham. Apabila dilihat dari kemampuan perusahaan dalam menghasilkan profitabilitas atas investasi yang dilakukan rata-rata sebesar 13,3\%. Pertahun. Nilai ini masih diatas tingkat suku bunga SBI bulanan tertinggi selama periode penelitian sebesar $12,75 \%$. Selama periode penelitian aktivitas operasional perusahaan dibiayai dengan hutang ratarata sebesar $14.5 \%$, sisanya dibiayai dengan modal sendiri dan bentuk lainnya. Berdasarkan data penelitian dan hasil perhitungan SPSS diperoleh persamaan sebagai berikut:

DPR $=26,821-23,063$ Investasi -0,216 likwiditas + 0,580 Size + 0,780 Profitabilitas 36,253 leverage

+ et

Model persamaan diatas dapat diartikan bahwa Investasi yang dilakukan perusahaan akan menurunkan pembayaran dividen perusahaan. Temuan ini sejalan dengan likwiditas, bahwa tingginya kebutuhan likwiditas akan menurunkan pembayaran dividen. Demikian juga leverage, makin tinggi pembiayaan perusahaan dari sumber ekternal akan menurunkan pembayaran dividen kepada pemegang saham. Berbeda dengan ukuran perusahaan makin besar ukuran perusahaan akan mendukung perusahaan untuk membayar dividen dengan membagi sebagian labanya kepada para pemegang saham. Hasil ini sejalan dengan profitabilitas, makin tinggi profit yang dihasilkan maka dividen yang dibayarkan akan makin tinggi pula.

Secara statistik penelitian telah memenuhi uji asumsi klasik. Data penelitian terdistribusi normal dan tidak terdapat masalah multikolinierity dimana VIF $<10$. Selain itu autokorelasi juga tidak terjadi karena hasil statistik Durbin Watson sebesar 1.326, (lampiran. 2) nilai ini lebih besar dari -2 dan lebih kecil dari 2.

Uji Statistik simultan ditemukan bahwa kelima variabel bebas penelitian secara bersama sama mempengaruhi kebijakan dividen perusahaan sebesar $61 \%$ sedangkan sisanya dipengaruhi oleh variabel lain. Hasil ini ditunjukkan dari nilai sign test sebesar $0.00<0.05$. Secara parsial investasi, profitabilitas dan leverage berpengaruh signifikan terhadap kebijakan dividen yang ditunjukkan dengan nilai sign test lebih kecil dari 0.05. Sementara likwiditas dan size tidak berpengaruh signifikan terhadap kebijakan dividen 
yang diperkuat hasil sign statistik lebih besar dari 0.05 (tabel 1,2)

Investasi yang diproksi dengan earning price ratio, profitabilitas yang diproksi dengan ROI serta leverage yang di proksi oleh debt to total asset berpengaruhi signifikan terhadap kebijakan dividen pada saham kelompok LQ 45. Sedangkan Likwiditas yang diproksi oleh cash ratio dan ukuran perusahaan (size) yang diproksi dengan ln sales tidak signifikan mempengaruhi kebijakan dividen kas.

Kebutuhan investasi yang tinggi dapat dibiayai dari sumber internal dan eksternal. Salah satu sumber internal perusahaan adalah profit perusahaan. Hasil penelitian ini menyatakan bahwa kebutuhan investasi perusahaan dalam kelompok LQ 45 sebagian didanai oleh sumber internal yang berdampak terhadap kebijakan dividen yang rendah. Hasil temuan ini juga dapat dikatakan bahwa perusahaan dalam kelompok LQ 45 pada umumnya memiliki pertumbuhan yang tinggi sebesar $11 \%$. Sehingga kegiatan investasi mempengaruhi kebijakan dividen secara dominan diantara variabel lainnya Temuan ini sejalan dengan studi yang dilakukan oleh Easterbrook (1984), bahwa investasi yang dilakukan perusahaan akan mempengaruhi kebijakan dividen, karena investasi membutuhkan dana. Williams (2012) menyatakan bahwa perusahaan bernilai tinggi memilih investasi dan dividen bersama-sama untuk memisahkan diri dari perusahaan bernilai rendah. Dengan kata lain, dividen tidak dibayarkan dari sisa. Terkait dengan pendapat Williams, maka dapat dikatakan bahwa perusahaan yang masuk kelompok LQ 45 masuk dalam kategori bernilai tinggi karena secara bersama-sama melakukan investasi dan dividen secara seimbang tidak saling meniadakan.

Tabel 1. Hasil Statistik dan Uji Statistik t test

\begin{tabular}{|c|c|c|c|c|c|c|c|}
\hline \multirow[b]{2}{*}{ Model } & \multicolumn{2}{|c|}{$\begin{array}{l}\text { Unstandardized } \\
\text { Coefficients }\end{array}$} & \multirow{2}{*}{$\begin{array}{c}\text { Standardized } \\
\text { Coefficients }\end{array}$} & \multirow[b]{2}{*}{$\mathrm{t}$} & \multirow[b]{2}{*}{ Sig. } & \multicolumn{2}{|c|}{ Collinearity Statistics } \\
\hline & $\mathrm{B}$ & Std. Error & & & & Tolerance & VIF \\
\hline 1 (Constant) & 26.821 & 5.452 & & 4.919 & .000 & & \\
\hline EPR & -23.063 & 4.531 & -.239 & -5.091 & .000 & .980 & 1.021 \\
\hline $\mathrm{CR}$ & -.216 & .374 & -.027 & -.577 & .565 & 983 & 1.017 \\
\hline Sales & .580 & .328 & .086 & 1.765 & .079 & 919 & 1.088 \\
\hline ROI & .780 & .098 & .394 & 7.918 & .000 & 874 & 1.145 \\
\hline DTA & -36.253 & 8.047 & -.224 & -4.505 & .000 & .876 & 1.141 \\
\hline
\end{tabular}

Tabel 2. Hasil Statistik ANOVA

\begin{tabular}{|c|c|c|c|c|c|c|}
\hline \multicolumn{7}{|c|}{ ANOVA $^{\mathbf{a}}$} \\
\hline Model & & $\begin{array}{l}\text { Sum of } \\
\text { Squares }\end{array}$ & df & Mean Square & $\mathrm{F}$ & Sig. \\
\hline \multirow{3}{*}{1} & Regression & 46352.960 & 5 & 9270.592 & 34.266 & $.000^{\mathrm{b}}$ \\
\hline & Residual & 78728.388 & 291 & 270.544 & & \\
\hline & Total & 125081.348 & 296 & & & \\
\hline
\end{tabular}

a. Dependent Variable: DPR

b. Predictors: (Constant), DTA, CR, EPR, Sales, ROI

Sejalan dengan investasi, variabel leverage berdampak negatif terhadap kebijakan dividen perusahaan. Hasil ini menunjukkan bahwa tingginya hutang telah menurunkan pembagian dividen kas perusahaan. Hal ini dapat disimpulkan bahwa perusahaan dalam kelompok LQ 45 pada umumnya membagi laba perusahaan untuk dividen kas dengan 
porsi tertentu tergantung besarnya investasi dan hutang perusahaan. Apabila kebutuhan investasi tinggi maka sebagian akan didanai dari sumber internal dan eksternal dengan menambah hutang. Hutang yang digunakan untuk membiayai investasi pada dasarnya bisa dibayar dengan hutang baru, namun banyak perusahaan membayar hutang dengan laba perusahaan sehingga berdampak pada penurunan dividen. Bila dikaitkan dengan teori Signaling yang menyatakan bahwa perusahaan akan membagi dividen kepada pemegang saham untuk memberi signal positif bahwa perusahaan memiliki prospek investasi yang baik karena selain membayar dividen tunai tampaknya perusahaan juga melakukan investasi yang dibiayai sebagian dari sumber internal yaitu laba perusahaan. Selain itu temuan ini juga sejalan dengan bird in the hand theory dimana perusahaan akan membayarkan kepastian dividen kas kepada pemegang saham. Bila ditinjau dari teori struktur modal, maka temuan ini dapat mendukung pecking order theory, dimana perusahaan tampaknya membiayai investasinya dari sumber internal dan hutang.Walaupun pembiayaan sumber internal yang dilakukan tetap mempertimbangkan pembagian dividen kas kepada pemegang saham. Tampaknya perusahaan yang masuk dalam kelompok LQ 45 berusaha untuk memperkecil masalah keagenan dengan menjaga keseimbangan antara pembayaran dividen dan pembiayaan untuk investasi. Karena pada dasarnya pemegang saham mempunyai kepentingan untuk mendapatkan dividen sedangkan agen (manajemen) lebih memilih untuk meningkatkan kesejahteraan.

Salah satu aspek penting dari kegiatan perusahaan bagaimana mendapatkan profit. Profit yang dihasilkan dapat digunakan untuk menambah modal atau dibagikan sebagai dividen. Apabila profit digunakan untuk menambah modal dan diinvestasikan pada peluang investasi yang menghasilkan NPV positif diharapkan mampu meningkatkan nilai perusahaan dengan maksimum. Konsekwensi dari penggunaan laba untuk menambah modal adalah dividen yang dibagikan menjadi berkurang apabila sumber pembagian dividen adalah laba. Dalam penelitian ini ditemukan hasil bahwa profitabilitas mempengaruhi secara positif pembayaran dividen dan signifikan. Hasil temuan ini menunjukkan bahwa bila laba perusahaan meningkat maka dividen juga akan meningkat. Bila dikaitkan dengan signaling theory, maka saat laba perusahaan meningkat perusahaan akan memberikan signal positif dengan cara menaikan dividen yang akan atau sudah dihasilkan dari investasi yang dilakukan.

Likuiditas perusahaan merupakan pertimbangan utama dalam banyak kebijakan dividen. Karena dividen bagi perusahaan merupakan kas keluar, maka semakin besar posisi kas dan likuiditas perusahaan secara keseluruhan akan semakin besar kemampuan perusahaan untuk membayar dividen. Perusahaan yang sedang mengalami pertumbuhan dan profitable akan memerlukan dana yang cukup besar untuk membiayai investasinya, oleh karena itu mungkin akan kurang likuid karena dana yang diperoleh lebih banyak diinvestasikan pada aktiva tetap dan aktiva lancar yang permanen. Penelitian ini menghasilkan temuan bahwa Likwiditas perusahaan berpengaruh negatif terhadap kebijakan dividen namun tidak signifikan. Masalah likwiditas bagi perusahaan dalam kelompok LQ 45 tampaknya bukan menjadi penentu utama dalam kebijakan dividen yang akan dibayarkan kepada pemegang saham. Perusahaan tetap konsisten akan membayar dividen perusahaan tanpa mempertimbangkan alasan likwiditas atau kebutuhan dana lainnya.

Size secara positif berpengaruh terhadap kebijakan dividen namun tidak signifikan. Artinya besarnya ukuran perusahaan akan memudahkan untuk mencari sumber pembiayaan eksternal melalui pasar modal baik dalam bentuk pinjaman jangka panjang 
(bond) maupun bentuk kepemilikan (saham). Di lain pihak, dividen kas juga tetap dibayarkan kepada pemegang saham. Bila perusahaan memiliki kemampuan untuk meminjam dengan mudah, maka dapat dikatakan perusahaan tersebut fleksibel secara keuangan. Semakin besar kemampuan perusahaan untuk meminjam, maka akan semakin besar fleksibilitasnya untuk meminjam, dan semakin besar pula kemampuannya untuk membayar dividen tunai. Dengan adanya akses yang mudah untuk berhutang, maka perusahaan tidak perlu terlalu khawatir dengan pengaruh dividen tunai dan likuiditasnya.

Kebijakan pembayaran dividen kas ini tampaknya dilakukan untuk mendukung bird in the hand theory karena investor lebih menyukai dividen yang sudah pasti dibandingkan capital gain. Terkait dengan teori tersebut tampaknya pemegang saham perusahaan dalam kelompok LQ 45 didominasi oleh investor institusional. Rata-rata jumlah pemegang saham institusional sebesar 49\%, dengan nilai maksimum $100 \%$ dan terendah sebesar $0,01 \%$. Pemegang saham institusional lebih menyukai dividen tinggi karena pemegang saham institusi diatas 25\% tidak dikenakan pajak (bukan objek pajak pph pasal 23). Oleh sebab itu perusahaan yang didominasi oleh pemegang saham institusi akan berusaha memberikan dividen secara kontinyu dan besar. Kebijakan perusahaan dengan pertimbangan kelompok pemegang saham lebih mengacu pada clientele theory.

\section{PENUTUP}

Berdasarkan hasil analisis dan pembahasan maka dapat disimpulkan sebagai berikut: (1) Variabel yang secara signifikan mempengaruhi kebijakan dividen kelompok perusahaan LQ 45 adalah investasi, profitabilitas, dan leverage perusahaan; (2) Variabel ukuran perusahaan dan likwiditas tidak signifikan mempengaruhi kebijakan dividen. Artinya besar kecilnya ukuran perusahaan dan tinggi rendahnya likwiditas tidak dapat dipertimbangkan untuk menentukan dividen yang akan dibayarkan; (3) Dua variabel yang paling menentukan kebijakan dividen adalah Investasi dan leverage dengan pengaruh negatif. Hasil ini menunjukkan bahwa kegiatan investasi dan kebijakan leverage yang dilakukan perusahaan dalam kelompok LQ 45 akan berdampak terhadap pengurangan dividen. Peningkatan hutang berdampak pada penurunan dividen karena harus membayar kewajiban yang diambil dari laba perusahaan; (4) Teori kebijakan dividen yang umumnya terjadi di BEI khususnya perusahaan dalam kelompok LQ 45 adalah signalling theory dan clientile theory.

\section{DAFTAR RUJUKAN}

Abbas. Assd, Hashmi. Shujahat Haider, Christi. Anwar Fazal. (2016) Dividend Policy and Capital Structure: testing Endogeneity https://papers.ssrn.com/sol3/papers2.cfm?abstract_id=2745726

Ardestani. Hananeh Shahteimoori, Rasid. Siti Zaleha Abdul, Basiruddin Rohaida, Mehri. Mohammadghorban. (2013) "Dividend Payout Policy, Investment Opportunity Set and Corporate Financing in the Industrial Products Sector of Malaysia". Journal of Applied Finance \& Banking, 3 (1)

Azhagaiah. R \& Sabarai Priya N. (2008) “The Impact of Dividend Policy on Shareholders' Wealth". International Research Journal of Finance and Economics

Ang Robert, (2010) Buku Pintar Pasar modal Indonesia. 7 th Ed. Jakarta. Mediasoft.

Bhattacharya. S, (1979) "Imperfect Information, Dividend Policy and The Bird in The 
Hand", Journal of Economics (Spring).

Denis, David J. dan Igor Osobov. (2007) Why do Firms Pay Dividends? International

Evidence on the Determinants of Dividend Policy. Available on-line at www.ssrn.com

Easterbrook, F H., (1984) "Two Agency Cost Explanation of Dividends", American Economic Review, September.

Harahap. Ludwina \& Wardhani. Ratna, (2013) Analisis Komprehensif Pengaruh Family Ownership, Masalah Keagenan, Kebijakan Dividen, Kebijakan Hutang, Corporate Governance dan Opportunity Growth Terhadap Nilai Perusahaan. Pascasarjana FEUI. https://downloadjurnals.files.wordpress.com/2013/06/065-cg-11.pdf

Hasnawati. Sri., (2005) "Implikasi Keputusan Investasi,Pendanaan, dan Dividen Terhadap Nilai Perusahaan Publik di Bursa Efek Jakarta”. Manajemen \& Usahawan: No.09/Th XXXIX. September 2005

Jensen, Michael C \& Meckling, William H., (1976) "Theory of the Firm:Managerial Behavior, Agency Costs, and Ownership Structure", Journal of Financial Economics, 3(4), October.

Lintner, J., (1962) "Dividend, Earning, Leverage, Stock Prices, and the Supply of Capital to Corporation," Review of Economics and Statistics,

Modigliani, F \& Miller, M.H, (1961) "Dividend Policy, Growth and the Valuation of Shares", J ournal of Business, October.

Mollah. Sabur. (2014) "Do Emerging Market Firms Follow Different Dividend Policies? Emperical Investigation on the Pre and Post reform Dividend policy and Behaviour of Dhaka Stock Exchange Listed Firms". Stidies in Economics and Finance, Vol 28. https://papers.ssrn.com/sol3/papers2.cfm?abstract_id=1462099

Muthusamy, K \& John. SF. (2010) "Leverage, growth and profitability as Determinants of dividend payout ratio-evidence from Indian paper Industry". Asian Journal of Business Management Studies,idosi.or.

Murhadi. Werner R. (2008) "Studi Kebijakan Dividen: Anteseden dan dampaknya Terhadap Harga Saham". Jurnal Ekonomi Manajemen. 10 (1).

Nguyen. K.H. (2014) "Impact of a Dividend Initiation Wave on Shareholder Wealth". Journal Applied Financial Economics. Vol 24.

Nurhayati. Mafizatun. (2013) "Profitabilitas, Likwiditas, dan ukuran Perusahaan Pengaruhnya terhadap kebijakan Dividen dan Nilai perusahaan sektor non Jasa". Jurnal keuangan dan Bisnis, 5 (2).

Ozumomba C.N, Anichebe A.S., Okoye P.V.C. (2016) "The effect of Dividend Policies on Wealth Masimizarion- a Study of Some selected Plcs". Journal Cogent Business $\backslash$ \&Management. Vol 3.

Priya. P. Vidhya \& Mohanasundari M. Dividend Policy and Impact on Firm Value: A Review of Theories and Empirical Evidence. Journal of Management Sciences and Technology. 3. Pengganti Litner 52 dan MM

Sartono R Agus. (2008) Manajemen Keuangan Teori, dan Aplikasi. Yogyakarta: BPFE .

Subramaniam K. Ravichandran,. Shaiban S. Mohammed, (2011) Investment Opportunity Set and Dividend Policy in Malaysia: Some Evidence on the Role of Ethnicity and Family Control. International Conference on Economics, Business and Management.

Sunariyah, (2010) Pengantar Pengetahuan Pasar Modal. Edisi Keenam. Yogyakarta. UPP STIM YKPN. 
Sugeng. Bambang, (2016) “The Effect of Dividend Initiation on Shortrun Return in Indonesia Stock Market: An Event Study With Propensity Score Matchingf Approach". International Journal of Business \& Management. 11 (12).

Van Horne, James C., John M. Machowicz., (2012) Financial Management and Policy. Ed 13. Terjemahan Salemba empat. Jakarta

Valipour, Hashem; Rostami. Vahab; Salehi. Mahdi. (2009) "Asymmetric Information and Dividend Policy in Emerging Markets: Emperical Evidences from Iran". International Journal of Economics and Finance, 1 (1).

Vojtech M. Cindy, (2012) The Relationship Beetween Information Asdymmetry and Dividend Policy. Finance and Economics Discussion Series Divisions of Research \& Statistics and Monetary Affairs Federal Reserve Board, Washington, D. C. https://www.federalreserve.gov/pubs/feds/2012/201213/201213pap.pdf

Wheelen, Thomas L \& Hunger, David. J., (2014) Strategic Management Business Policy, 13th Ed, Prentice Hill Upper Saddle River, New Jersey.

Williams. Joseph, (2012) "Efficient Signalling with Dividend, Investment, and Stock Repurchases. The American Finance Association", Publichers of The Journal of Finance.

Zainuddin. Achmad. (2012) "Pengaruh Ukuran Perusahaan terhadap Praktek Pengungkapan Sosial dan Lingkungan Pada Perusahaan Manufaktur Go Publik". Jurnal Admisi \& Bisnis Versi Online. ISSN1411-4321. http://admisibisnis.blogspot.co.id/2012/04/pengaruh-ukuran-perusahaanterhadap.html 


\section{Lampiran 1. Descriptive Statistics}

\begin{tabular}{|l|r|r|r|}
\hline \multicolumn{3}{|c|}{ Descriptive Statistics } \\
\hline & Mean & Std. Deviation & N \\
\hline DPR & 37.6551 & 20.55656 & 297 \\
\hline EPR & .1129 & .21320 & 297 \\
\hline CR & 2.4358 & 2.57751 & 297 \\
\hline Sales & 15.3504 & 3.03560 & 297 \\
\hline ROI & 13.2570 & 10.38606 & 297 \\
\hline DTA & .1455 & .12690 & 297 \\
\hline
\end{tabular}

\section{Lampiran 2. Model Summaryb}

\begin{tabular}{|c|c|c|c|c|c|c|c|c|c|c|}
\hline \multirow[b]{2}{*}{ Model } & \multirow[b]{2}{*}{$\mathrm{R}$} & \multirow[b]{2}{*}{$\begin{array}{c}\mathrm{R} \\
\text { Square }\end{array}$} & \multirow[b]{2}{*}{$\begin{array}{l}\text { Adjusted } \\
\text { R Square }\end{array}$} & \multirow{2}{*}{$\begin{array}{l}\text { Std. Error } \\
\text { of the } \\
\text { Estimate }\end{array}$} & \multicolumn{5}{|c|}{ Change Statistics } & \multirow[b]{2}{*}{$\begin{array}{l}\text { Durbin- } \\
\text { Watson }\end{array}$} \\
\hline & & & & & $\begin{array}{l}\text { R Square } \\
\text { Change }\end{array}$ & F Change & df1 & df 2 & Sig. F Change & \\
\hline 1 & $.609^{\mathrm{a}}$ & .371 & .360 & 16.44823 & .371 & 34.266 & 5 & 291 & .000 & 1.326 \\
\hline
\end{tabular}

a. Predictors: (Constant), DTA, CR, EPR, Sales, ROI

b. Dependent Variable: DPR 